\title{
Kerangka Konseptual Kualitas Layanan Elektronik Dan Perilaku Konsumen Melalui Customer Perceived Value
}

\author{
Dhita Dhora Damayanti \\ Universitas Islam Lamongan, Indonesia \\ Email corresponding author: dhitadhora@unisla.ac.id
}

\begin{abstract}
ABSTRAK
Tujuan: Industri jasa penting untuk menentukan desain layanan baik secara konvensional maupun elektronik yang berkualitas. Pada masa pandemi seperti saat ini, penyedia jasa layanan yang tidak bisa melayani secara tatap muka perlu mempertimbangkan untuk meningkatkan kualitas layanan elektroniknya untuk tetap bisa menciptakan kepuasan pada pelanggannya. Tujuan dari artikel ini adalah untuk memberikan kerangka konseptual terkait kualitas layanan elektronik pada bidang jasa yang dimediasi oleh Customer perceived value. Metode: Metode yang digunakan dalam artikel ini adalah dengan literatur riview dimana meninjau artikel-artikel yang berkaitan dengan kualitas layanan elektronik yang diterbitkan di emerald.com terutama di dalam bidang jasa. Hasil: Dari hasil tinjauan literartur ditemukan bahwa selain mempengaruhi kepuasan pelanggan baik secara langsung maupun melalui customer perceived value, kualitas layanan elektronik juga bisa mempengaruhi hal-hal lain bagi penyedia jasa. Jika kepuasan berorientasi pada pelanggan, maka pengauruh kualitas layanan elektronik bisa mempengaruhi perusahaan dalam hal citra perusahaan yang baik dan WoM Kontribusi: Artikel ini diharapkan mampu memberikan konsep baru terkait penelitian tentang kualitas layanan elektronik. Mengingat saat ini adalah era pandemic penyedia jasa layanan bisa focus mendesain layanan elektronik mereka untuk meningkatkan kepuasan dan perilaku konsumennya yang bisa berpengaruh baik pada perusahaan dalam jangka pendek maupun jangka panjang,
\end{abstract}

Kata Kunci: Kualitas Layanan, Kualitas Layanan Elektrionik, E-ServQual, Kepuasan Pelanggan, Customer Perceived Value

\section{ABSTRACT}

Objective: The service industry is important to determine the quality of service design both conventionally and electronically. During the current pandemic, service providers who cannot serve face-to-face need to consider improving the quality of their electronic services in order to continue to create satisfaction for their customers. The purpose of this article is to provide a conceptual framework related to the quality of electronic services in the service sector mediated by customer perceived value. Method: The method used in this article is a literature review which reviews articles related to the quality of electronic services published on emerald.com, especially in the service sector. Results: From the results of the literature review, it was found that in addition to influencing customer satisfaction both directly and through customer perceived value, the quality of electronic services can also affect other things for service providers. If satisfaction is customer-oriented, then the influence of the quality of electronic services can affect the company in terms of a good corporate image and WoM Contribution: This article is expected to provide a new concept related to research on the quality of electronic services. Considering that this is a pandemic era, service providers can focus on designing their electronic services to improve customer satisfaction and behavior which can affect both the company in the short and long term, 
Keywords: Service Quality, Electronic Service Quality, E-ServQual, Customer Satisfaction, Customer Perceived Value

\section{PENDAHULUAN}

Pertumbuhan Internet yang luar biasa mengubah cara perusahaan menjalankan bisnis dengan pelanggannya. Perusahaan penyedia jasa tidak terkecuali. Sayangnya, meskipun penyedia jasa dengan layanan elektronik telah memfokuskan perhatian mereka pada peningkatan kualitas layanan mereka, banyak dari mereka tampaknya masih tertinggal di belakang tuntutan dan harapan pelanggan mereka yang terus meningkat.

Penyedia Layanan Jasa adalah perusahaan atau Lembaga pemerintahan yang melayanai konsumen dan pelanggan melalui jasa-jasa yang diberikan. Misalnya travel agent, hotel, bank, Lembaga pemerintah, restoran dan bidang jasa lainnya. Kualitas layanan saat ini tidak hanya berorientasi pada kualitas layanan konvensional. Terutama di masa pandemic saat ini, bank perlu memperluas strategi kualitas layanan secara elektronik.

Untuk bertahan dalam industri jasa yang sangat kompetitif, jelas bahwa industry jasa perlu menyediakan layanan berkualitas tinggi kepada pelanggan. Ada banyak penelitian yang mengidentifikasi dimensi kualitas layanan utama dalam lingkungan penyedia jasa tradisional, di mana interaksi pribadi antara pelanggan dan karyawan penyedia jasa merupakan penyampaian layanan dan saluran komunikasi utama. Namun tidak banyak yang memuat literatur terkait pengukuran kualitas layanan elektronik (e-SQ).

Terkait dengan dimensi kualitas layanan elektronik, banyak penelitian sebelumnya menentukan dimensi yang membentuk kualitas layanan elektronik. Barnes dan Vidgen (2002) mengembangkan untuk mengukur penawaran e-commerce organisasi atau yang disebut dengan WebQual. Skala ini memberikan indeks kualitas situs yang diukur melaluipersepsi pelanggan dan memiliki lima faktor yaitu kegunaan, desain, informasi, kepercayaan, dan empati.

Meskipun secara tidak langsung bertemu dengan pelanggan namun kualitas layanan elektronik sama pentingnya dalam mempengaruhi kepuasan pelanggan. Selain dari pada itu, sebelum masuk pada kepuasan pelanggan, kualitas layanan elektronik juga bisa berpengaruh secara tidak langsung namun melalui variable Customer perceived value. Studi yang dilakukan oleh (Ekinci et al., 2008) mengungkapkan bahwa pengaruh kualitas layanan yang dirasakan terhadap kepuasan pelanggan telah ditetapkan dan ditunjukkan dalam beberapa penelitian. Liao (2011) percaya bahwa kinerja hubungan pelanggan sangat bergantung pada karakteristik layanan elektronik. Tetapi kekuatan hubungan dapat terpengaruh ketika bisnis menggunakan layanan multisaluran (misalnya, menawarkan layanan online dan offline).

Kepuasan Pelanggan mempengaruhi banyak hal terkait dengan perilaku konsumen. Slack (2020) menyatakan bahwa ada hubungan positif antara kepuasan pelanggan dengan behavioural intention. Kepuasan pelanggan yang dibentuk melalui kualitas layanan elektronik khususnya memang akan berdampak pada banyak hal. Baik bagi pelanggan yang menikmati layanan tersebut hingga berdampak pada keberlangsungan perusahaan penyedia jasa layanan. Oleh karena itu, artikel ini bertujuan untuk memberikan gambaran secara konseptual terkait kualitas layanan elektronik melalui Customer perceived value. Berdasarkan latar belakang diatas, maka pertanyaan dari artikel ini adalah:

1. Apakah Kualitas layanan secara positif mempengaruhi Customer Perceived Value?

2. Apakah Kualitas layanan melalui customer perceived value secara positif mampu memediasi kepuasan pelanggan?

3. Apakah Customer Perceived Value secara langsung dapat mempengaruhi kepuasan pelanggan?

4. Apakah Kualitas Layanan secara positif mempengaruhi kepuasan pelanggan?

5. Apakah Kualitas layanan secara positif berpengaruh pada Citra perusahaan?

6. Apakah Citra perusahaan secara positif berpengaruh pada Niat berkunjung kembali?

7. Apakah Kualitas Layanan secara positif berpengaruh pada WoM? 
8. Apakah Kepuasan pelanggan secara positif berpengaruh pada WoM?

\section{LITERATUR REVIEW}

\section{Kualitas Layanan Elektronik}

Parasuraman et. al (2005, p. 217) mendefinisikan e-SQ sebagai sejauh mana situs web memfasilitasi belanja, pembelian dan pengiriman yang efisien dan efektif. Definisi ini memperjelas bahwa konsep e-SQ meluas dari fase pra-pembelian (kemudahan penggunaan, informasi produk, informasi pemesanan, dan perlindungan informasi pribadi) hingga fase pasca pembelian (pengiriman, dukungan pelanggan, pemenuhan, dan kebijakan pengembalian). Lingkungan online berbeda dari konteks ritel tradisional dalam beberapa hal. Ini dapat diringkas sebagai berikut:

a. Kenyamanan dan efisiensi: Konsumen yang menggunakan lingkungan online memiliki kemudahan dalam menghemat waktu dan tenaga dalam membandingkan harga (dan beberapa fitur teknis) produk secara lebih efisien (Santos, 2003).

b. Keamanan dan kerahasiaan: Partisipasi dalam lingkungan online melibatkan pengguna dalam masalah khusus terkait privasi, keamanan, dan kerahasiaan.

c. Tidak adanya kontak tatap muka: Pelanggan di lingkungan online berinteraksi dengan antarmuka teknis (Fassnacht dan Koese, 2006). Tidak adanya interaksi orang-ke-orang berarti bahwa konsep tradisional dan cara mengukur kualitas layanan, yang menekankan interaksi pribadi dari pertemuan layanan konvensional, tidak memadai bila diterapkan pada e-SQ (van Riel et al., 2001).

d. Produksi bersama kualitas layanan: Pelanggan di lingkungan online memainkan peran yang lebih menonjol dalam memproduksi bersama layanan yang diberikan daripada kasus dalam konteks ritel tradisional (Fassnacht dan Koese, 2006).

Penelitian lain terkait layanan elektronik juga dikemukakan oleh Yoo dan Donthu (2001) yang mengembangkan skala SITEQUAL dengan sembilan item untuk mengukur kualitas situs pada empat dimensi:

1. Kemudahan penggunaan

2. Desain estetika

3. Kecepatan pemrosesan

4. Keamanan.

Kekurangan pengukuran dengan SITEQUAL adalah tidak menangkap semua aspek dari proses pembelian dan oleh karena itu bukan merupakan penilaian komprehensif dari kualitas layanan situs. Pengukuran lain dikemukakan oleh Wolfinbarger dan Gilly (2003) dengan mengembangkan pengukuran yang disebut eTailQ. Skala tersebut berisi empat faktor yaitu:

1. Desain situs web, melibatkan beberapa atribut yang terkait dengan desain serta item yang berhubungan dengan personalisasi dan yang lainnya berhubungan dengan pemilihan produk

2. Keandalan/pemenuhan, melibatkan representasi produk yang akurat, pengiriman tepat waktu, dan pesanan yang akurat

3. Privasi/keamanan, perasaan aman dan mempercayai situs

4. Layanan pelanggan, menggabungkan minat dalam memecahkan masalah, kesediaan personel untuk membantu, dan jawaban cepat untuk pertanyaan.

Meskipun berbagai macam dimensi yang membentuk kualitas layanan elektronik namun pada dasarnya layanan yang berkualitas akan memberikan efek yang baik pada kepuasan pelanggan baik secara langsung maupun melalui mediasi customer perceived value. Selain dapat berpengaruh pada kepuasan, kualitas layanan juga dapat berpengaruh pada kepercayaan pelanggan terhadap jasa layanan yang diberikan. 


\section{Kualitas Layanan pada Customer Perceived Value}

Kualitas layanan yang melalui customer perceived value adalah konsep abstrak dengan makna yang bervariasi tergantung pada konteksnya dan biasanya didefinisikan dari sudut pandang pelanggan (Morar, 2013). Secara umum dapat diterima bahwa kualitas layanan adalah perbandingan pelanggan antara harapan mereka terhadap layanan yang ditawarkan dan persepsi mereka tentang layanan yang sebenarnya diterima dan bahwa kualitas layanan merupakan salah satu faktor penentu keberhasilan bagi perusahaan jasa. seperti restoran (Zeithaml et al., 2009). Konsep pemasaran lain yang banyak digunakan, yaitu nilai yang dirasakan pelanggan, disarankan untuk terdiri dari pertukaran oleh pelanggan antara semua manfaat yang diperoleh dari penawaran bisnis yang diterima sebagai lawan dari pengorbanan yang harus dilakukan oleh pelanggan untuk mendapatkan manfaat).

Memberikan nilai kepada pelanggan sekarang bisa dibilang salah satu elemen terpenting dari strategi pemasaran yang cukup ampuh karena sebagian besar aktivitas pemasaran diarahkan untuk menciptakan nilai yang dirasakan pelanggan. Oleh karena itu studi menyebutkan bahwa Kualitas layanan secara positif mempengaruhi customer perceived value (Clemes et al., 2011; Ha dan Jang, 2013). Sehingga dari pernyataan diatas maka dapat ditentukan preposisi sebagai berikut:

P1: Kualitas layanan secara positif mempengaruhi Customer Perceived Value

\section{Customer Perceived Value pada Kepuasan Pelanggan}

Berbagai variasi dalam mendefinisikan konsep kepuasan pelanggan ada dalam literatur yang ada, disarankan bahwa tiga konstituen umum terkandung dalam setiap definisi, yaitu respons (emosional dan kognitif), respons ditargetkan terhadap produk atau layanan tertentu, harapan , pengalaman konsumsi, dll., dan respons terjadi pada waktu tertentu (seperti setelah konsumsi) (Giese dan Cote, 2000, hlm. 3).

Nilai dan kepuasan pelanggan diterima secara luas sebagai harapan utama keinginan pelanggan untuk dipenuhi dari pengalaman bersantap di restoran (Clemes et al., 2011). Selanjutnya, bukti empiris dari berbagai penelitian mendukung hubungan kausal antara nilai dan kepuasan. Studi lain juga mengkonfirmasi nilai yang dirasakan pelanggan merupakan anteseden terhadap kepuasan pelanggan berkorelasi sangat positif dengan kepuasan pelanggan dan prediktor kepuasan pelanggan yang andal (Thielemann et al., 2018; Williams et al., 2017). Kepuasan pelanggan tergantung pada persepsi pelanggan tentang nilai yang dirasakan, dan bahwa niat masa depan pelanggan sangat ditentukan oleh nilai yang dirasakan pelanggan. Mengakui harapan pelanggan ini, dan keterkaitan yang kuat dan pengaruh nilai yang dirasakan pelanggan terhadap kepuasan pelanggan, pemilik restoran dan pemasar terus mengembangkan strategi baru untuk memberikan nilai pelanggan untuk meningkatkan kepuasan pelanggan, dan pada akhirnya meningkatkan jangka panjang dan kesuksesan bisnis. Melihat kaitan antara kualitas layanan elektronik, customer perceived value dan kepuasan pelanggan maka dapat dibentuk preposisi sebagai berikut:

P2: Kualitas layanan melalui customer perceived value secara positif mampu memediasi kepuasan pelanggan

P3: Customer Perceived Value secara langsung dapat mempengaruhi kepuasan pelanggan

\section{Kualitas layanan elektronik pada Kepuasan Pelanggan}

Menurut Kotler (2008) yang dapat membentuk ekspektasi konsumen atau pelanggan dapat berasal dari beberapa hal yaitu: pengalaman pembelian masa lalu, nasihat teman dan rekan, serta informasi dan janji pemasar dan pesaing. Kepuasan pelanggan akan meningkat saat layanan yang diberikan melebihi nilai yang dirasakan pelanggan. Pertukaran informasi merupakan hal yang penting untuk memahami perubahan kebutuhan dan perilaku pelanggan sehingga perusahaan dapat menyesuaikan produk untuk individu (Mei Mei Lau, 2013) 
Pada dasarnya, kepuasan adalah perasaan tentang rasa senang atau kecewa dari pelanggan yang timbul karena membandingkan ekspektasi dari sebuah layanan dengan kenyataan yang didapat setelah menerima atau mengalami langsung pelayanan tersebut. Setidaknya ada sepuluh teori kepuasan pelanggan yang terstruktur dalam tiga perspektif pokok:

1. Perspetif psikologi

2. Perspektif ekonomi

3. Perspektif sosiologi

Liao (2011) percaya bahwa kinerja hubungan pelanggan sangat bergantung pada karakteristik layanan elektronik. Tetapi kekuatan hubungan dapat terpengaruh ketika bisnis menggunakan layanan multisaluran (misalnya, menawarkan layanan online dan offline). Dia lebih lanjut berpendapat bahwa layanan multichannel, setiap inkonsistensi dalam kualitas yang dirasakan di seluruh saluran dapat mengakibatkan ketidakpercayaan pelanggan terhadap penyedia layanan. Dalam studi lain oleh Chang dan Wang (2011) menyelidiki pengaruh kualitas layanan elektronik, nilai yang dirasakan pelanggan, dan kepuasan pelanggan terhadap loyalitas pelanggan dalam lingkungan belanja online. Ditemukan bahwa kualitas layanan elektronik dan nilai yang dirasakan pelanggan memengaruhi kepuasan pelanggan, dan kemudian memengaruhi loyalitas pelanggan. Selain itu, terungkap bahwa pelanggan dengan nilai yang dirasakan tinggi memiliki hubungan yang lebih kuat antara kepuasan dan loyalitas pelanggan daripada pelanggan dengan nilai yang dirasakan rendah.

Pembentukan kepercayaan didasarkan pada pengamatan dan pengalaman interaksi dengan mitra, kepuasan yang berkelanjutan sering kali mengarah pada kepercayaan. Kepuasan dapat terbentuk dalam waktu yang relatif singkat melalui interaksi sebelumnya, yang secara positif mempengaruhi loyalitas. Kepuasan pelanggan dianggap sebagai faktor penting dari hubungan perusahaan dengan konsumen dan penentu utama loyalitas (Cronin et al., 2000). Hal ini menguraikan penilaian pasca pengalaman konsumen dari suatu produk maupun layanan (Mittal dan Frennea, 2010). Dengan berbagai literatur diatas maka dapat dirumuskan preposisi sebagai berikut:

P4: Kualitas Layanan secara positif mempengaruhi kepuasan pelanggan

\section{Kualitas Layanan elektronik pada Citra Perusahaan dan Niat Berkunjung Kembali}

Citra perusahaan mengacu pada persepsi pelanggan terhadap citra organisasi. Menurut Virvilaite dan Daubaraite (2011), citra perusahaan merupakan suatu bentuk keunggulan bersaing yang sulit ditiru oleh pesaing karena hanya dapat dikembangkan dalam jangka waktu yang lama. Oleh karena itu, mempertahankan citra perusahaan yang positif sangat penting karena secara signifikan mempengaruhi keputusan pembelian kembali pelanggan dan kesediaan untuk memberikan informasi dari WoM. Quintal dan Polczynski (2010) menggambarkan niat berkunjung kembali sebagai penilaian pelanggan tentang kemungkinan mengunjungi kembali tujuan yang sama. Dalam jangka panjang, niat perilaku tersebut akan berkontribusi pada profitabilitas bisnis (Jani dan Han, 2014). Di sisi lain, ketika citra perusahaan menguntungkan, pelanggan lebih mungkin menyebarkan berita positif dari WoM.

Citra perusahaan dipandang sebagai variabel intervening yang bertindak sebagai mediator antara kualitas layanan dan niat perilaku termasuk loyalitas, niat mengunjungi kembali dan dari WoM. Misalnya, Lai et al. (2009) menemukan bahwa kualitas layanan yang lebih tinggi secara signifikan meningkatkan citra perusahaan, yang pada gilirannya meningkatkan niat perilaku. Konsisten dengan penelitian sebelumnya, citra perusahaan harus memiliki pengaruh positif yang signifikan terhadap kunjungan kembali. Sehingga dari teoriteroi tersebut dapat dirumuskan preposisi sebagai berikut:

\section{P5: Kualitas layanan secara positif berpengaruh pada Citra perusahaan}

P6: Citra perusahaan secara positif berpengaruh pada Niat berkunjung kembali 


\section{Kualitas layanan elektronik, Kepuasan pelanggan pada Word of Mouth (WoM)}

Dalam layanan keuangan seperti perbankan, WoMmemiliki arti penting yang lebih besar, karena berdampak pada profitabilitas bank (Tang et al., 2016). ). Jadi, untuk layanan seperti perbankan, nasabah sangat bergantung pada saran dan saran dari orang lain yang telah mengalami layanan tersebut (Mukerjee, 2018).

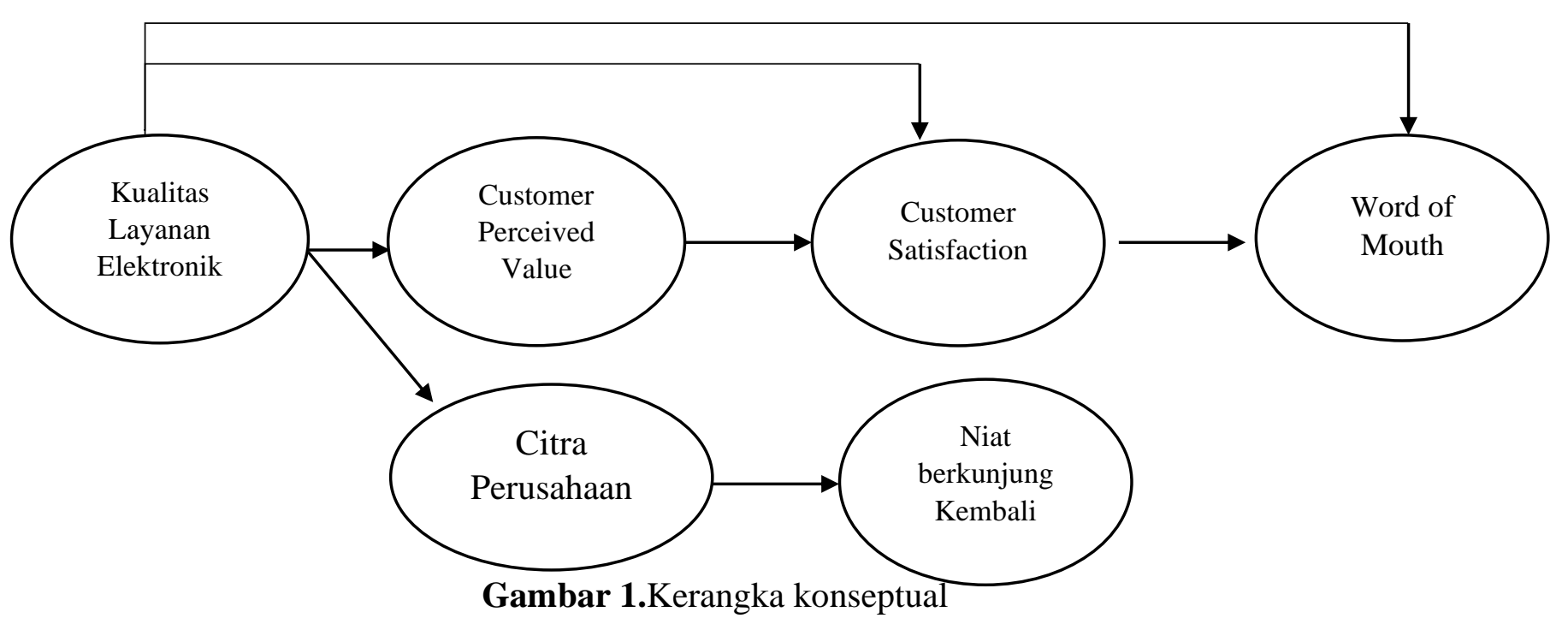

WoM telah didefinisikan sebagai tindakan konsumen memberikan informasi tentang barang, jasa, merek, atau perusahaan kepada konsumen lain. Studi tentang WoM telah difokuskan pada valensi WoM, volume word-of-mouth, pengaruh kekuatan ikatan pada perilaku pengirim dan penerima dari WoM, serta anteseden dan konsekuensi dari dari WoM. Literatur yang ada menunjukkan bahwa WoM dipengaruhi oleh kepuasan, loyalitas, nilai yang dirasakan dan pengalaman pelanggan (Jalilvand et al., 2017; Rosario et al., 2016). Telah disebutkan bahwa dari WoM sangat penting bagi penyedia layanan yang penawarannya sebagian besar tidak berwujud, dan berbasis pengalaman atau kepercayaan (Balaji et al., 2017). Oleh karena itu jika sebuah penyedia jasa layanan mampu memberikan layanan yang berkualitas secara alamiah mampu mempengaruhi perilaku konsumen dalam melakukan WoM. Sehingga dapat dirumuskan proposisi sebagai berikut:

P7: Kualitas Layanan secara positif berpengaruh pada WoM

P8: Kepuasan pelanggan secara positif berpengaruh pada WoM

\section{KESIMPULAN}

Secara teoritis menunjukkan bahwa kualitas layanan elektronik mampu menjawab proposi yang dibentuk dalam artikel ini. Kualitas layanan mampu mempengaruhi berbagai aspek yang dapat meningkatkan nilai jual dari perusahaan. Beberapa literatur juga mengungkapkan bahwa kualitas layanan elektronik saat ini mampu meningkatkan kepuasan pelanggan bahkan lebih lanjut dapat mempengaruhi banyak hal yang lebih dari kepuasan. Dampak kualitas layanan tidak hanya dirasakan sampai batas kepuasan pelanggan saja melanikan mampu mempengaruhi citra perusahaan dan meningkatkan WoM.

Citra perusahaan dan WoM adalah hal yang mahal dan tidak dengan mudah di dapat. Ketika konsumen atau pelanggan mulai merekomendasikan jasa layanan yang kita berikan maka artinya pelanggan telah melewati banyak fase yang memenuhi ekspektasi dan harapan mereka. Dengan tidak perlu mengeluarkan ekstra dana untuk melakukan promosi demi 
meningkatkan citra perusahaan, kualitas layanan yang memenuhi ekspektasi dan memuaskan pelanggan dapat menjawab hal tersebut.

Dari beberapa literatur yang membahas tentang pengukuran kualitas layanan elektronik bertujuan mengukur kualitas layanan situs Web dan layanan elektronik. Aspek pengalaman lainnya seperti kesenangan atau kesenangan tidak termasuk dalam domain konseptual kualitas layanan Di sisi lain, memahami interaksi antara manfaat yang dicari dari sebuah situs dan kualitas layanan situs. Artikel ini tidak semata-mata paling benar. Penulis pun mengakui bahwa masih ada kekurangan pada studi ini. Artikel ini ditinjau dari beberapa penelitian terdahulu yang hanya berkaitan dengan kualitas layanan elektronik dan kepuasan pelanggan saja. Sehingga diharapkan untuk penelitian selanjutnya dapat menambah variable-variabel yang berkaitan dengan nilai kepercayaan, loyalitas, dan perilaku pasca pembelian. Selain itu diharapkan untuk penelitian selanjutnya dapat meninjau lebih dalam secara empiris terkait dengan hubungan variable-variabel ini.

Artikel ini tentunya dapat menjadi pertimbangan bagi manajerial terutama bagi para pemasar untuk dapat memilih skala pengukuran kualitas layanan elektronik yang sesuai dengan kebutuhan perusahaan mereka. Dengan menentukan skala pengukuran yang tepat maka diharapkan manajerial dapat mendesain layanan elektronik yang sesuai dengan kebutuhan perusahaan Apabila ditinjau secara praktis, artikel ini mampu membantu manajerial khususnya tenaga pemasar, untuk lebih berorientasi pada pelanggan apabila ingin mendapatkan kepuasan pelanggan yang bisa berdampak jangka panjang terkait citra perusahaan dan WoM.

\section{DAFTRA PUSTAKA}

Barnes, Stuart J. and Richard T. Vidgen (2002), "An Integrative Approach to the Assessment of E-Commerce Quality," Journal of Electronic Commerce Research, 3 (3), 114-27.

Chang, H. H. and H. W. Wang (2011). The moderating effect of customer perceived value on online shopping behaviour. Online Information Review, 35(3): 333-359

Clemes, M.D., Gan, C. and Ren, M. (2011), "Synthesizing the effects of service quality, value and customer satisfaction on behavioural intentions in the motel industry: an empirical analysis", Journal of Hospitality and Tourism Research, Vol. 35 No. 4, pp. 530-568.

Ekinci, Y., Dawes, P. L., and Massey, G. R. (2008). An extended model of the antecedents and consequences of consumer satisfaction for hospitality services. European Journal of Marketing, 42(1/2): 35-68.

Fassnacht, M. and Koese, I. (2006), "Quality of electronic services, conceptualizing and testing a hierarchical model”, Journal of Service Research, Vol. 9 No. 1, pp. 19-37.

Giese, J.L. and Cote, J.A. (2000), "Defining consumer behaviour", Academy of Marketing Science Review, Vol. 2000 No. 1, pp. 1-24.

Kim Leng Khoo, (2020), "A study of service quality, corporate image, customer satisfaction, revisit intention and word-of mouth: evidence from the KTV industry", PSU Research Review.

Liao, M., and Yen, et al. (2011). The effect of channel quality inconsistency on the association between e-service quality and customer relationships. Internet Research, 21(4): 4-4.

Morar, D.D. (2013), "An overview of the consumer value literature - perceived value, desired value", International Conference, Marketing From Information to Decision, 6th ed., pp. 69-186.

Neale J. Slack, Gurmeet Singh, and Jazbeen Ali, (2020), "Influence of fast-food restaurant service quality and its dimensions food restaurant on customer perceived value, satisfaction and behavioural intentions", British Food Journal .

Parasuraman, A., Zeithaml, V. and Malhotra, A. (2005). E-S-QUAL: A multiple-item scale for assessing electronic service quality. Journal of Service Research, 7(3): 213-33. 
Santos, J. (2003), "E-Service quality: a model of virtual service quality dimensions", Managing Service Quality, Vol. 13 No. 3, pp. 233-46.

Susanti, I., Syairozi, M. I., \& Lukman, H. Y. W. (2021). Analisis Sistem Manajemen Dalam Pengelolaan Bumdes Di Desa Bluluk. Jurnal Sains Sosio Humaniora, 5(2), 701-710.

Syairozi, M. I. (2017). Percepatan Pengurangan Kemiskinan Sektor Pertanian di Kabupaten Malang. In Seminar Nasional \& Call For Paper, FEB Unikama (pp. 145-155).

Thielemann, V.M., Ottenbacher, M.C. and Harrington, R.J. (2018), "Antecedents and consequences of perceived customer value in the restaurant industry: a preliminary test of a holistic model", International Hospitality Review, Vol. 32 No. 1, pp. 26-45.

Van Riel, A.C., Liljander, V. and Jurriens, P. (2001), "Exploring consumer evaluations of eservices: a portal site", International Journal of Service Industry Management, Vol. 12 No. 4, pp. 359-377.

Yoo, Boonghee and Naveen Donthu (2001), "Developing a Scale to Mea- sure the Perceived Quality of an Internet Shopping Site (Sitequal)," Quarterly Journal of Electronic Commerce, 2 (1), 31-46.

Wijaya, K., \& Syairozi, M. I. (2020). Analisis perpindahan tenaga kerja informal Kabupaten Pasuruan. Jurnal Paradigma Ekonomika, 15(2), 173-182. 